Case Report

\title{
Intrascrotal Collection in an Acute Pancreatitis: A Case Report and Review of the Literature
}

\author{
L. Moens, ${ }^{1}$ P. Yengue Yengue, ${ }^{2}$ and C. Assenmacher ${ }^{3}$ \\ ${ }^{1}$ Catholic University of Brussels, Brussels, Belgium \\ ${ }^{2}$ Department of Gastroenterology, CHwapi, Tournai, Belgium \\ ${ }^{3}$ Department of Urology, St. Elisabeth Hospital, Brussels, Belgium \\ Correspondence should be addressed to L. Moens; loic.moens@student.uclouvain.be
}

Received 17 January 2016; Accepted 25 July 2016

Academic Editor: Giorgio Carmignani

Copyright (C) 2016 L. Moens et al. This is an open access article distributed under the Creative Commons Attribution License, which permits unrestricted use, distribution, and reproduction in any medium, provided the original work is properly cited.

\begin{abstract}
Context. An inguinoscrotal swelling occurring during an acute pancreatitis is very rare. Case Report. We report a case of right inguinoscrotal swelling appearing in connection with an interstitial edematous acute pancreatitis. We have noticed a spontaneous complete reduction of the right inguinoscrotal swelling after 10 days. Conclusion. The management of a scrotal swelling should be the least invasive possible method but also the most complete possible method to avoid unnecessary interventions. The exclusion of a pathology that could affect the vital prognosis of the testis remains the absolute priority. An acute scrotum swelling must be carried out by the clinical management by a professional and must be completed with an ultrasonography of the scrotum. Despite all that, if the original etiology of the acute scrotum remains unknown, an abdominopelvic CT scan could provide more details and so could offer a different diagnosis of exclusion, different from the diagnosis of acute idiopathic scrotal edema (AISE). This rare complication of acute pancreatitis reported could be mistaken for a more common pathology. If that complication is identified, it will not require a surgical intervention if there is a correct management of the acute pancreatitis which could justify a broader CT scan.
\end{abstract}

\section{Introduction}

Initially the diagnosis of acute pancreatitis is based on the clinical examination associated with the lipase and amylase serum level. Apache II and SIRS are useful. The CT scan is not recommended directly but it is after 72 hours for moderate to severe acute pancreatitis to assess the presence of local complications [1]. There are acute peripancreatic fluids, pseudocysts, necrotic collections, vascular complications, ascitis, and pleural effusion. We have found seventeen cases in the literature (Table 1) presenting local complications extending into the scrotum. In those cases the complication reported had a potential interference for typical urologic differential diagnoses of acute scrotum.

\section{Case Report}

A 48-year-old male patient with a known diabetic, hypertensive, and hypercholesterolemic status called the Emergency
Department for abdominal pain not responding to the paracetamol and butylhyoscine bromide. He complained about increasing broad abdominal pain, nausea, and sweating. His daily treatment was fenofibrate, moxonidine, metformin, and enoxaparin $60 \mathrm{mg}$. He was a chronic consumer of alcohol. There was an abdominal guarding and pain increased by palpation. His blood test showed high lipase level of $14069 \mathrm{UI} / \mathrm{L}$ (regular range: <67 UI/L), a hyperleukocytosis with 14670 units/ $\mu \mathrm{L}$ (regular range: 4000 to 10000 units $/ \mu \mathrm{L}$ ), a hyperneutrophilia with 12264 units/ $\mu \mathrm{L}$ (regular range: 2400 to 7500 units $/ \mu \mathrm{L}$ ), a CRP level of $178 \mathrm{mg} / \mathrm{L}$ (normal range: $<5.0 \mathrm{mg} / \mathrm{L}$ ), a YGT serum level of $81 \mathrm{UI} / \mathrm{L}$ (normal range for a male: $15-73 \mathrm{UI} / \mathrm{L}$ ), a triglyceride serum level of $1560 \mathrm{mg} / \mathrm{dL}$, and finally a high blood sugar beyond the patient's regular range. Two days after admission a painful swelling of the right side of his scrotum in an afebrile context with a skin erythema appeared. The ultrasound scan showed an important heterogeneous effusion in the right scrotum and an infiltration of the right inguinal canal fat. The testis was homogenous, well 
TABLE 1: Literature reports of cases of inguinoscrotal and other extension of pancreatitis local complications.

\begin{tabular}{|c|c|c|c|c|c|}
\hline $\begin{array}{l}\text { References }+ \\
\text { year of } \\
\text { publication }\end{array}$ & Urologic clinical features & $\begin{array}{c}\text { Side } \\
\text { affected }\end{array}$ & $\begin{array}{l}\text { Etiology of the } \\
\text { pancreatitis }\end{array}$ & Atlanta classification & $\begin{array}{c}\text { Invasive scrotal interventions } \\
\text { (+intra-abdominal } \\
\text { interventions })\end{array}$ \\
\hline [2] 1979 & Unknown & Unknown & Unknown & $\begin{array}{l}\text { Supposed necrotizing } \\
\text { acute pancreatitis }\end{array}$ & Unknown \\
\hline [3] 1988 & $\begin{array}{l}\text { Painful scrotum } \\
\text { enlargement }\end{array}$ & Unknown & Alcohol & $\begin{array}{l}\text { Interstitial edematous } \\
\text { acute pancreatitis }\end{array}$ & NO \\
\hline [4] 1994 & $\begin{array}{l}\text { Transilluminating } \\
\text { hydrocele }\end{array}$ & Right & Alcohol & $\begin{array}{l}\text { Interstitial edematous } \\
\text { acute pancreatitis }\end{array}$ & NO \\
\hline [5] 1994 & $\begin{array}{l}\text { Painful and swollen } \\
\text { scrotum } \\
\text { Inguinal mass }\end{array}$ & Left & Unknown & $\begin{array}{c}\text { Necrotizing acute } \\
\text { pancreatitis }\end{array}$ & $\begin{array}{c}\mathrm{NO} \\
(+ \text { laparotomy) }\end{array}$ \\
\hline [6] 1995 & Scrotal necrosis & Unknown & Unknown & $\begin{array}{l}\text { Necrotizing acute } \\
\text { pancreatitis }\end{array}$ & $\begin{array}{l}\text { Excision of the testis and the } \\
\text { scrotum }\end{array}$ \\
\hline [7] 1996 & $\begin{array}{l}\text { Scrotal mass, erythematous } \\
\text { skin }\end{array}$ & Unknown & Latrogenic & $\begin{array}{l}\text { Necrotizing acute } \\
\text { pancreatitis }\end{array}$ & Invasive scrotal aspiration \\
\hline [8] 1996 & Tender swollen scrotum & Left & Alcohol & $\begin{array}{l}\text { Interstitial edematous } \\
\text { acute pancreatitis }\end{array}$ & NO \\
\hline [9] 2000 & Painful inguinal swelling & Right & Alcohol & $\begin{array}{l}\text { Interstitial edematous } \\
\text { acute pancreatitis }\end{array}$ & Percutaneous drainage \\
\hline [10] 2004 & Painful scrotal swelling & Right & Alcohol & $\begin{array}{l}\text { Interstitial edematous } \\
\text { acute pancreatitis }\end{array}$ & $\begin{array}{c}\text { Scrotal fluid punction } \\
\text { (+retroperitoneal drainage) }\end{array}$ \\
\hline [11] 2006 & Inguinoscrotal mass & Left & Alcohol & $\begin{array}{l}\text { Interstitial edematous } \\
\text { acute pancreatitis }\end{array}$ & $\mathrm{NO}$ \\
\hline [12] 2006 & Scrotal mobile mass & Right & Unknown & $\begin{array}{l}\text { Interstitial edematous } \\
\text { acute pancreatitis }\end{array}$ & Percutaneous drainage \\
\hline [13] 2007 & $\begin{array}{l}\text { Tender inguinoscrotal } \\
\text { swelling }\end{array}$ & Left & Alcohol & $\begin{array}{l}\text { Interstitial edematous } \\
\text { acute pancreatitis }\end{array}$ & $\begin{array}{l}\text { (Drainage of the } \\
\text { retroperitoneal collection) }\end{array}$ \\
\hline [14] 2008 & Scrotal exudation, fever & Bilateral & Alcohol & $\begin{array}{l}\text { Interstitial edematous } \\
\text { acute pancreatitis }\end{array}$ & $\begin{array}{l}\text { Scrotal debridement } \\
\text { (+ERCP, pancreatic duct } \\
\text { stenting) }\end{array}$ \\
\hline [15] 2008 & $\begin{array}{l}\text { Painful scrotal swelling, } \\
\text { fever, funiculitis }\end{array}$ & Left & Unknown & $\begin{array}{l}\text { Interstitial edematous } \\
\text { acute pancreatitis }\end{array}$ & Unknown \\
\hline [16] 2009 & $\begin{array}{l}\text { Painful scrotal swelling, } \\
\text { macroscopic hematuria }\end{array}$ & Left & Alcohol & $\begin{array}{l}\text { Interstitial edematous } \\
\text { acute pancreatitis }\end{array}$ & NO \\
\hline [17] 2011 & $\begin{array}{l}\text { Painful scrotal swelling, } \\
\text { discoloration of the } \\
\text { scrotum }\end{array}$ & Left & Alcohol & $\begin{array}{l}\text { Necrotizing acute } \\
\text { pancreatitis }\end{array}$ & $\mathrm{NO}$ \\
\hline [18] 2013 & $\begin{array}{l}\text { Painful tender groin and } \\
\text { scrotal swelling }\end{array}$ & Right & Unknown & $\begin{array}{l}\text { Interstitial edematous } \\
\text { acute pancreatitis }\end{array}$ & $\begin{array}{c}\text { NO } \\
(+ \text { drainage paracolic } \\
\text { collection })\end{array}$ \\
\hline Our case report & $\begin{array}{c}\text { Painful inguinoscrotal } \\
\text { swelling + skin erythema }\end{array}$ & Right & $\begin{array}{c}\text { Alcohol, } \\
\text { hypertriglyceridemia }\end{array}$ & $\begin{array}{l}\text { Interstitial edematous } \\
\text { acute pancreatitis }\end{array}$ & NO \\
\hline $\begin{array}{l}\text { References }+ \\
\text { year of } \\
\text { publication }\end{array}$ & Other expressions reported & $\begin{array}{c}\text { Side } \\
\text { affected }\end{array}$ & $\begin{array}{l}\text { Etiology of the } \\
\text { pancreatitis }\end{array}$ & Atlanta classification & Treatment reported \\
\hline [19] 1973 & Extension to the groin & Right & Alcohol & $\begin{array}{l}\text { Interstitial edematous } \\
\text { acute pancreatitis }\end{array}$ & Inguinal canal drainage \\
\hline [20] 1984 & Extension to the groin & Left & Alcohol & Unknown & $\begin{array}{c}\text { Laparotomy + peritoneal } \\
\text { lavage }\end{array}$ \\
\hline [21] 1987 & $\begin{array}{l}\text { Extension to the thigh and } \\
\text { the knee }\end{array}$ & Left & Gallstones & $\begin{array}{l}\text { Interstitial edematous } \\
\text { acute pancreatitis }\end{array}$ & Pseudocyst drainage \\
\hline [22] 2009 & $\begin{array}{c}\text { Extension to the psoas } \\
\text { muscle }\end{array}$ & Left & Alcohol & $\begin{array}{l}\text { Interstitial edematous } \\
\text { acute pancreatitis }\end{array}$ & Laparotomy + pancreatectomy \\
\hline
\end{tabular}




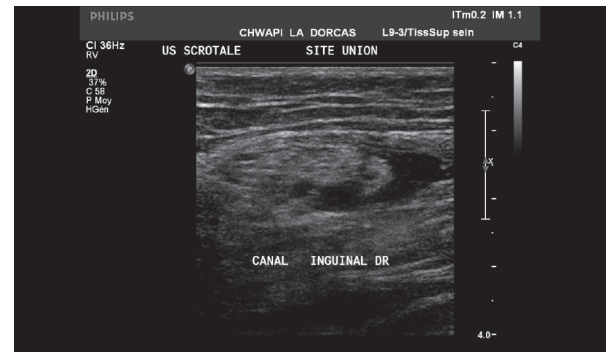

FIGURE 1: Ultrasound scan demonstrating an infiltration of the inguinal canal fat.

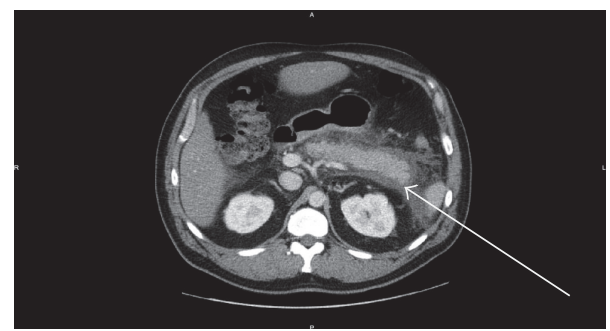

FIGURE 2: Axial contrast CT scan of the abdomen showing retroperitoneal and peritoneal effusion arising from the tail and the body of the pancreas 4 days after admission.

vascularised with a normal size and morphology (Figure 1). The contrast CT scan (Figures 2 and 3) was requested to discover the reason of this infiltration, which showed a peritoneal and retroperitoneal effusion infiltrating the retroperitoneal fat tissues extending from the body and the tail of the pancreas (Figure 2) to the right scrotum (Figure 4), following the iliopsoas muscle and filtering through the right inguinal canal (Figure 3). Finally we diagnosed a right inguinoscrotal swelling related to a mild acute pancreatitis probably induced by an overconsumption of alcohol mixed with a hypertriglyceridemia. He was discharged after 11 days without any specific treatment.

\section{Discussion}

"The acute scrotum is a clinical syndrome that is defined as an acute, painful swelling of the scrotum or its contents accompanied by local signs and general symptoms" [21]. Usually the literatures $[21,22]$ describe a variety of possible diagnoses as testicular torsion, torsion of testicular appendage, epididymitis, hernia, idiopathic scrotal edema, and tumor (listed in order of relative frequency). In case of acute scrotum it is necessary to exclude the diagnosis of testicular torsion quickly because of a risk of testicular loss in case of delay. The clinical examination seems to be the best way of finding the good diagnosis [21]. If not sufficient, the ultrasound scan with a Doppler is described as the best equipment in case of uncertain diagnosis $[20,22]$. As far as our case is concerned, the acute idiopathic scrotal edema (AISE) is often defined as a diagnosis of exclusion because of its unknown etiology. At the present time, AISE is supposed to be a hypersensitivity reaction related to a variant of angioneurotic

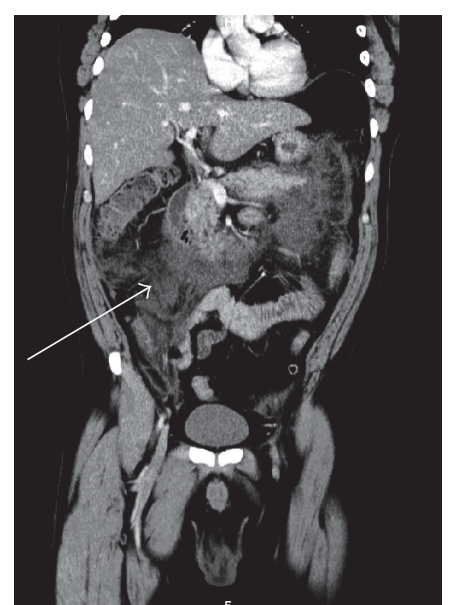

FIGURE 3: Frontal section contrast CT scan showing retroperitoneal effusion extending from the tail and the body of the pancreas.

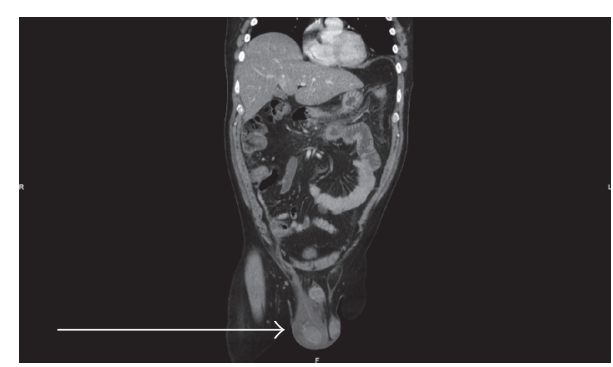

FIGURE 4: Frontal section contrast CT scan showing involvement of the right scrotum after 4 days of admission.

edema often associated with a hypereosinophilia in $77.8 \%$ and a hypervascularization [22].

We thought initially of local causes of unilateral inguinoscrotal swelling. That is the reason why we asked for an ultrasound scan and a Doppler to eliminate the diagnosis of testicle twist, orchiepididymitis, or even inguinal hernia, diagnosis that cannot be postponed. The testis was homogenous, normal sized, and well vascularized. It showed however an infiltration of the right inguinal canal fat with an heterogeneous effusion of the right scrotum. On the basis of the clinical findings and the high serum lipase level, the diagnosis of acute pancreatitis in a context of acute alcohol consumption was made. There were no biological and clinical criteria for a severe acute pancreatitis and so the patient was admitted in gastroenterology. There was no reason for intensive care. It occurred in a context of high consumption of alcohol, a high serum TG level, and a treatment by fenofibrate. We asked for a contrast abdominopelvic CT scan after $72 \mathrm{~h}$ which established a direct link between, on the one hand, the retroperitoneal effusion, what comes out the body and the tail of the pancreas and on the other hand the right inguinoscrotal swelling. This fluid dissects the anatomic plans and finds a way from the head and the tail of the pancreas to the scrotum. In this case we supposed that the processus vaginalis is well a remnant. 


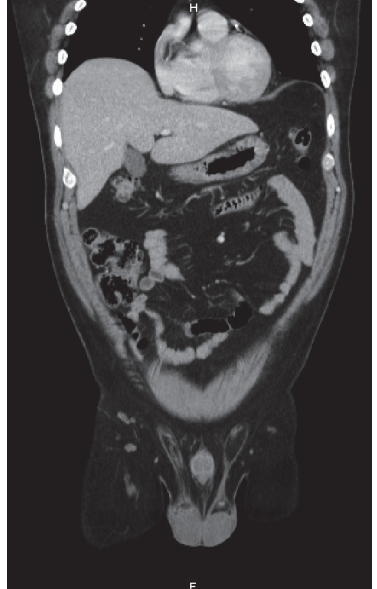

FIgURE 5: Comparative contrast CT scan after 1 month.

We decided to ensure the patient follow-up with a classic treatment because there was an absence of the pyretic signs usually indicating complications such as necrotizing infected tissues. There was a spontaneous resolution after 10 days (Figure 5).

After having examined the seventeen cases found (Table 1), we can suppose that for acute scrotum complicating an interstitial edematous acute pancreatitis we have the following:

(i) There is no preference for a side affected.

(ii) The most common etiology for much complicated acute pancreatitis remains the alcohol abuse.

(iii) The etiology was indeed found mainly by the CT scan.

(iv) Concerning the scrotum, the conservative treatment is mostly appropriate.

(v) The indications reported in the guidelines of acute pancreatitis remain the main source to justify an intra-abdominal invasive treatment (over infected collections not responding to antibiotics, etc.).

(vi) Drainage of intra-abdominal pancreatic collection seems to improve the resolution of acute scrotum.

Because of this rare complication we shall suggest a management combining the pancreatitis and the acute scrotum. By doing so, the number of mistakenly reported pathologies as common may decrease. If the common diagnosis is rejected, the scrotal swelling due to an unknown cause could be identified by mistake as an acute idiopathic scrotal edema (AISE). The low number of case reports describing this complication could explain the fact that there were no appropriate investigations. We suggest confirming the "good diagnosis of AISE" by excluding an intra-abdominal origin with an abdominopelvic CT scan. In this case we have supposed that if we exclude intraabdominal causes, the percentage of hypervascularized and the percentage of hypereosinophilia among "the entity described as a real AISE" could maybe rise.

Yet, we have compared the evolution and the treatment of related cases. The spontaneous resolution seen in our case reinforces the benefits of a noninvasive management whereby we have to remain particularly watchful of possible overcomplications such as infections of necrotized tissues. That is why the patient's supervision in the hospital is still required.

\section{Conclusion}

The management of a scrotal swelling should be the least invasive possible method but also the most complete possible method to avoid unnecessary interventions. The exclusion of a pathology that could affect the vital prognosis of the testis remains the absolute priority. An acute scrotum swelling must be carried out by the clinical management by a professional and must be completed with an ultrasonography of the scrotum. Despite all that, if the original etiology of the acute scrotum remains unknown, an abdominopelvic CT scan could provide more details and so could offer a different diagnosis of exclusion, different from the diagnosis of acute idiopathic scrotal edema (AISE). This rare complication of acute pancreatitis could be mistaken for a more common pathology and if that complication is identified, it will not require a surgical intervention if there is a correct management of the acute pancreatitis which could justify a broader CT scan.

\section{Competing Interests}

The authors declare that they have no competing interests.

\section{References}

[1] S. S. Vege, "Management of acute pancreatitis: literature review," 2015.

[2] A. F. Zimin, V. N. Satsukevich, and N. P. Molchanov, "Acute pancreatitis with hemorrhagic flow into the scrotum," Vestnik khirurgii imeni I. I. Grekova, vol. 122, no. 3, pp. 47-48, 1979.

[3] J. Delamarre, P. Descombes, G. Grillot, B. Deschepper, and H. Deramond, "Hydrocele of pancreatic origin. X-ray computed tomographic study of an intrascrotal collection in an acute outbreak of chronic pancreatitis," Journal de Radiologie, vol. 69, no. 11, pp. 689-690, 1988.

[4] B. Isgar, R. J. Blunt, and A. P. Wolinski, "Pancreatitis presenting with unilateral scrotal pain and swelling," British Journal of Surgery, vol. 81, no. 1, p. 101, 1994.

[5] K. Wolfson and G. S. Sudakoff, "Ultrasonography and color Doppler imaging of a scrotal phlegmon in an acute necrotizing pancreatitis," Journal of Ultrasound in Medicine, vol. 13, no. 7, pp. 190-193, 1994.

[6] J. J. Martínez Bengoechea, F. Ortega Villar, Y. Mengod Guillen, and J. Lazaro Maisanava, "Scrotal digestion caused by pancreatic ascites," Actas Urologicas Españolas, vol. 19, no. 4, pp. 320321, 1995.

[7] K. K. L. Choong, "Acute penoscrotal edema due to acute necrotizing pancreatitis," Journal of Ultrasound in Medicine, vol. 15, no. 3, pp. 247-248, 1996.

[8] Y.-L. Lin, M.-T. Lin, G.-T. Huang et al., "Acute pancreatitis masquerading as testicular torsion," The American Journal of Emergency Medicine, vol. 14, no. 7, pp. 654-655, 1996. 
[9] V. Z. Erzurum, R. Obermeyer, and D. Chung, "Pancreatic pseudocyst masquerading as an incarcerated inguinal hernia," Southern Medical Journal, vol. 93, no. 2, pp. 221-222, 2000.

[10] A. D. Lee, D. T. Abraham, S. Agarwal, and B. Perakath, "The scrotum in pancreatitis: a case report and literature review," Journal of the Pancreas, vol. 5, no. 5, pp. 357-359, 2004.

[11] K.-L. Liu, T.-C. Lee, and H.-P. Wang, "A tender scrotum and inguinal mass caused by pancreatitis," Clinical Gastroenterology and Hepatology, vol. 4, no. 12, p. A26, 2006.

[12] A. Michalopoulos, V. Papadopoulos, S. Apostolidis, T. Papavramidis, D. Paramythiotis, and P. Berovalis, "A rare case of pancreatic pseudocyst masquerading as hydrocele," Acta Gastro-Enterologica Belgica, vol. 69, no. 4, p. 424, 2006.

[13] M. A. Nazar, F. R. D’Souza, A. Ray, and M. A. Memon, "Unusual presentation of acute pancreatitis: an irreducible inguinoscrotal swelling mimicking a strangulated hernia," Abdominal Imaging, vol. 32, no. 1, pp. 116-118, 2007.

[14] M. Atiq, I. Budhani, R. Snyder, K. Safdar, A. Khan, and S. Chauhan, "Pancreatic hydrocele: an unusual manifestation of severe acute pancreatitis," Gastrointestinal Endoscopy, vol. 68, no. 2, pp. 393-395, 2008.

[15] B. R. Diego, A. C. Tubet, G. J. Banos, M. B. Garcia, P. J. Martin, and Z. S. Guerrero, "Scrotal mass as result of the extension of a pancreatic pseudocyst," Actas Urológicas Españolas, vol. 32, no. 2, pp. 261-264, 2008.

[16] F. Pinard, J.-R. Pennarun, O. Develay et al., "Orchi-epididymitis? No, acute pancreatitis," Gastroentérologie Clinique et Biologique, vol. 33, no. 10-11, pp. 1054-1056, 2009.

[17] S.-B. Kim, B.-K. Je, S. H. Lee, and S. H. Cha, "Scrotal swelling caused by acute necrotizing pancreatitis: CT diagnosis," Abdominal Imaging, vol. 36, no. 2, pp. 218-221, 2011.

[18] C. Skouras, T. Skouras, M. Pai, E. Zacharakis, and D. Spalding, "Inguinoscrotal extension of a pancreatic collection: a rare complication of pancreatitis-case report and review of the literature," Updates in Surgery, vol. 65, no. 2, pp. 153-159, 2013.

[19] A. F. Salvo and H. Nematolahi, "Distant dissection of a pancreatic pseudocyst into the right groin," The American Journal of Surgery, vol. 126, no. 3, pp. 430-432, 1973.

[20] A. R. Dennison and G. T. Royle, "Acute pancreatitispresentation as a discoloured lump in the groin," Postgraduate Medical Journal, vol. 60, no. 703, pp. 374-375, 1984.

[21] D. J. Lye, R. H. Stark, G. M. Cullen, and J. F. Wepfer, "Ruptured pancreatic pseudocyst: extension into the thigh," American Journal of Roentgenology, vol. 149, no. 5, pp. 937-938, 1987.

[22] Y. Tajima, T. Mishima, T. Kuroki et al., "Huge pancreatic pseudocyst migrating to the psoas muscle and inguinal region," Surgery, vol. 145, no. 3, pp. 341-342, 2009. 


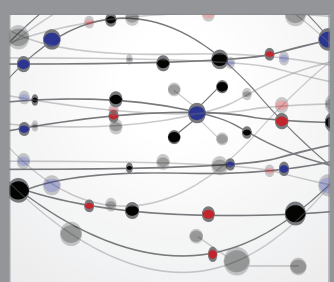

The Scientific World Journal
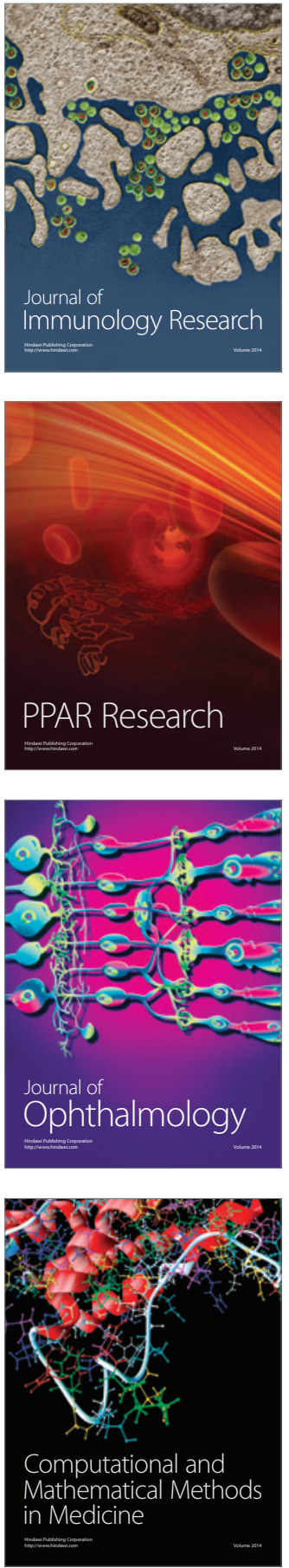

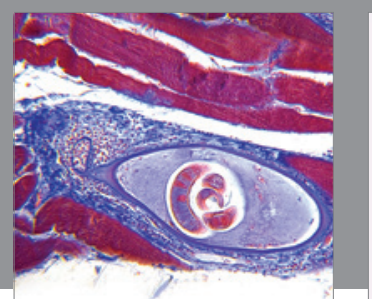

Gastroenterology Research and Practice

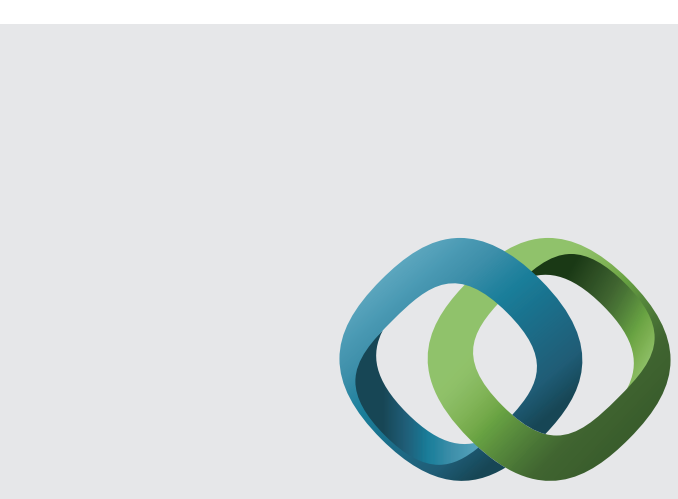

\section{Hindawi}

Submit your manuscripts at

http://www.hindawi.com
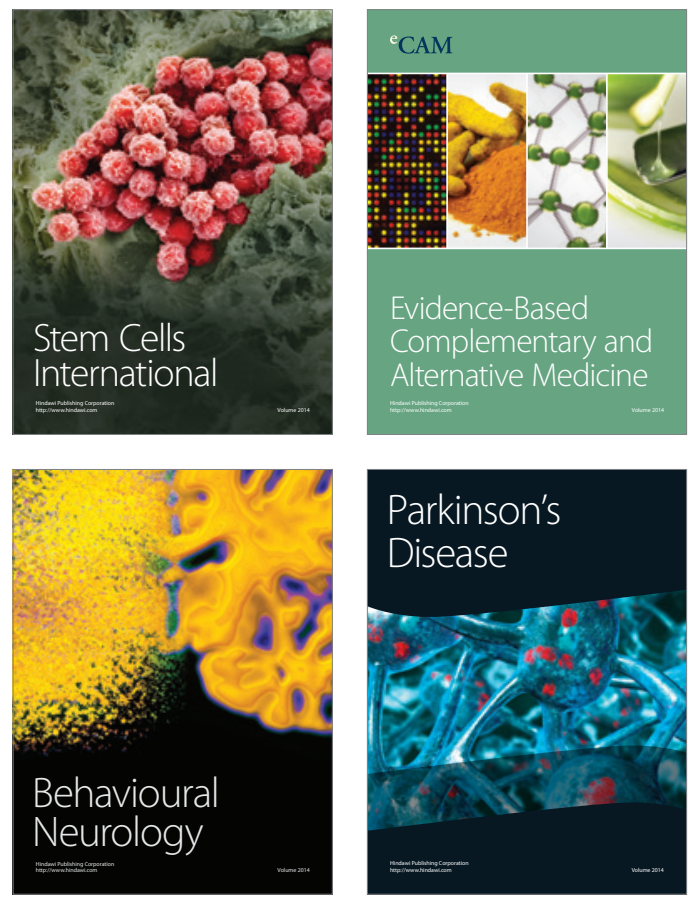
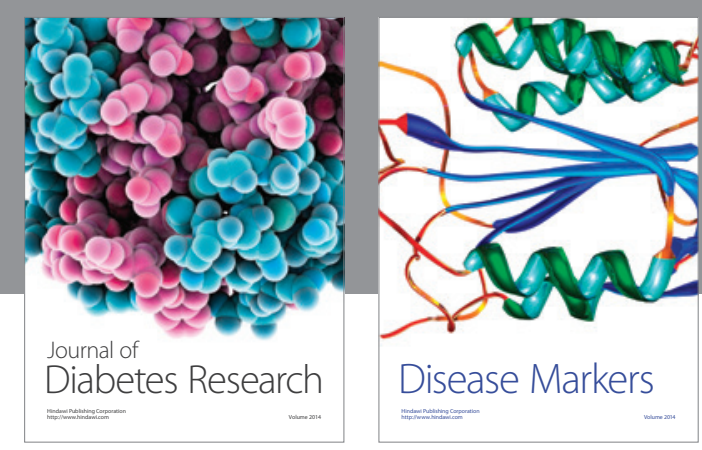

Disease Markers
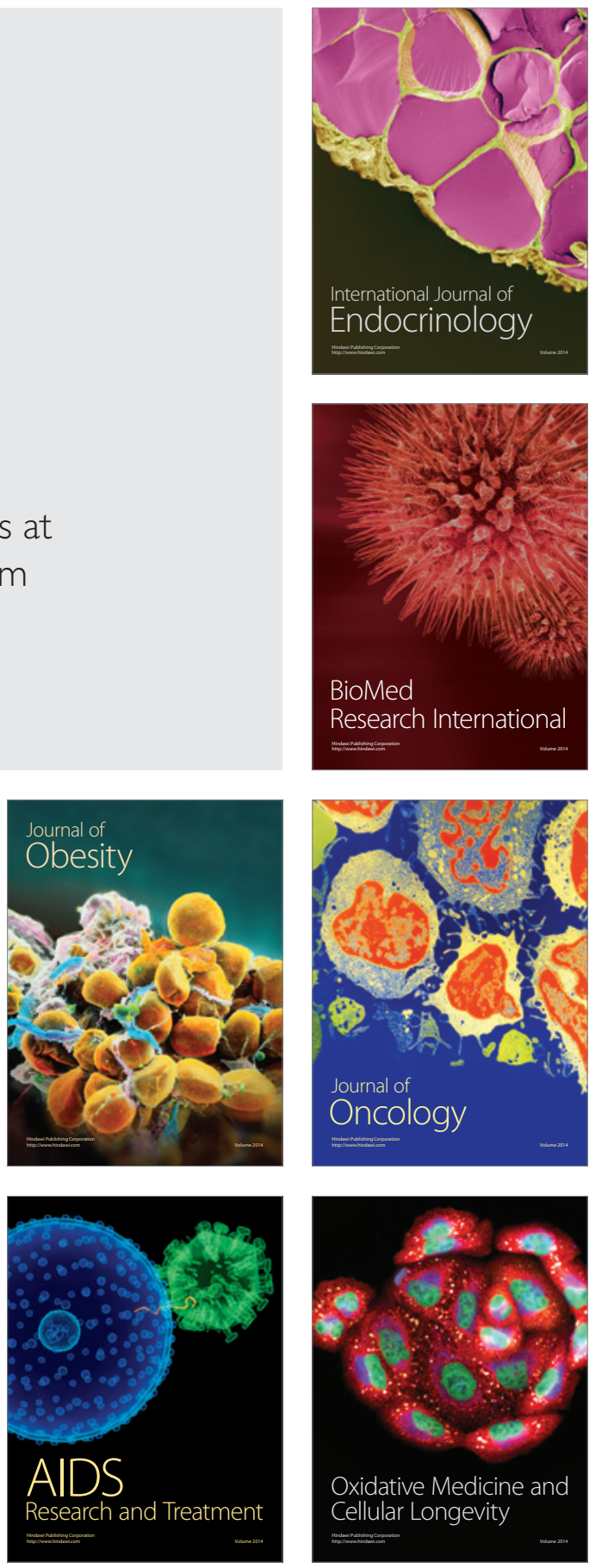